\title{
Rates of amino acid uptake and mineralization in Resurrection Bay (Alaska) sediments
}

\author{
Susan F. Sugai, Susan M. Henrichs* \\ Institute of Marine Science, School of Fisheries and Ocean Sciences, University of Alaska Fairbanks, Fairbanks, \\ Alaska 99775-1080, USA
}

\begin{abstract}
The rates of uptake and mineralization of glutamic acid, alanine, lysine, serine and glycine were measured in sediments from Resurrection Bay, Alaska, USA, using ${ }^{14} \mathrm{C}$-labeled amino acids. Amino acid concentrations and specific activities were determined by high performance liquid chromatography. The fate of radiolabeled amino acids added to killed control sediments was also investigated. Free amino acids were lost from the dissolved pool by both bacterial uptake and adsorption to sediment particles. Adsorption was the dominant process for the basic amino acid lysine and was responsible for about half of the glutamic acid and alanine removal from solution. Rates of bacterial mineralization of porewater amino acids, calculated using a model which corrects for the effects of adsorption, were 8 (glutamic acid), 1 (alanine), 0.7 (lysine), 1 (serine) and 3 (glycine) nmol cm ${ }^{-3}$ sediment $\mathrm{d}^{-1}$. These rates indicate that amino acids could be quantitatively important intermediates in the mineralization of organic nitrogen in this sediment.
\end{abstract}

\section{INTRODUCTION}

One model of organic matter decomposition in sediments involves the release of soluble organic molecules by the action of bacteria on macromolecules (Krom \& Sholkovitz 1977, Christensen \& Blackburn 1980). The dissolved compounds are rapidly assimilated and metabolized by bacteria. This hypothesis suggests an approach to the study of the rates and pathways of organic matter mineralization in sediments: measuring the rate of decomposition of dissolved intermediates in the process, such as amino acids or low-molecular-weight carboxylic acids. This is most easily done by observing the fate of radiolabeled compounds added to sediments.

Acetate has been the most-studied intermediate (Sansone \& Martens 1981, Christensen \& Blackburn 1982, Shaw et al. 1984), because it is a major product of the fermentation of sediment organic matter and can be a substrate for both sulfate reducers and methanogens. Interpretation of the results of experiments proved difficult, however. The problems identified so far include adsorption of radiotracer by sediment particles (Shaw et al. 1984, Sansone et al. 1987) and possible complexation of acetate by dissolved organic macromolecules in porewaters (Christensen \&
Blackburn 1982, Parkes et al. 1984). One symptom of the continuing uncertainty in these measurements is that the apparent rates of acetate oxidation were often 2 or more times greater than rates of sulfate reduction (Christensen \& Blackburn 1982, Shaw et al. 1984), which is not consistent with the fact that sulfate was the major electron-acceptor for organic matter oxidation in the sediments studied.

Amino acids have also been the subjects of several studies (Christensen \& Blackburn 1980, Meyer-Reil 1986, Burdige 1989). Christensen \& Blackburn (1980) investigated alanine metabolism in Limfjord, Denmark, sediments. They found that 30 to $40 \%$ of the added radiotracer was rapidly adsorbed to sediment particles over a wide concentration range ( 36 to $230 \mathrm{nM}$ ) and that adsorbed alanine decomposed much more slowly than dissolved alanine. The apparent alanine mineralization rate in Limfjord sediments was 3 times greater than the ammonia production rate. Christensen \& Blackburn (1980) hypothesized that alanine, like acetate, could be 'complexed' by macromolecules in porewater, rendering it unavailable to microorganisms.

We report here results of a study of the uptake and mineralization of 5 amino acids (alanine, glutamic acid, glycine, serine and lysine) in Resurrection Bay, Alaska, USA, sediments. These amino acids were selected 
because, together, they make up $80 \%$ of the total dissolved free amino acids in porewaters of this sediment. Also, they represent 4 different groups based on their side-chain properties: acidic (glutamic acid), aliphatic (alanine, glycine), basic (lysine) and hydroxy (serine) amino acids. The objectives of this research were to determine the quantitative importance of amino acids as intermediates in the mineralization of sediment organic nitrogen and to investigate the effects of adsorption on amino acid uptake and mineralization rates.

\section{MATERIALS AND METHODS}

Sampling. Sediments were collected from a depth of $60 \mathrm{~m}$ in Thumb Cove, Resurrection Bay, during November 1986 . Thumb Cove sediments are glacially derived silt containing 0.6 to $0.7 \%$ dry wt organic carbon. The bottom water temperature was $8^{\circ} \mathrm{C}$ and its oxygen concentration was $6 \mathrm{ml} \mathrm{l}^{-1}$. Sediments were collected with a MK-III box corer (Ocean Instruments, San Diego, CA, USA). After removing the overlying water, the sediment was subsampled by placing a pair of rectangular sheet-metal plates vertically into the box. Gas-tight incubation syringes (14 $\mathrm{mm}$ i.d.) (Alperin \& Reeburgh 1985) were inserted horizontally into the sediment through holes drilled in one of the plates at a depth of $4.5 \mathrm{~cm}$ below the sediment surface. During September-October 1989, sediments were collected at the Thumb Cove site using a 'Haps'-type corer. After removal of the overlying water, syringes were inserted vertically into the sediment, sampling the 0 to $6 \mathrm{~cm}$ depth interval.

Uptake and mineralization rates. After filling, the syringes were sealed with Teflon-faced silicone septa and aluminum crimp seals. The syringes were injected with $10 \mu \mathrm{l}$ of a 4 to $6 \mu \mathrm{M}\left[\mathrm{U}-{ }^{14} \mathrm{C}\right.$ ]alanine, [U- $\left.{ }^{14} \mathrm{C}\right]-$ glutamic acid, [U- $\left.{ }^{14} \mathrm{C}\right]$ glycine, $\left[\mathrm{U}-{ }^{14} \mathrm{C}\right]$ serine or [U- $\left.{ }^{14} \mathrm{C}\right]-$ lysine solution in seawater; the injections were made in 3 , approximately $3 \mu$ increments. $\left[\mathrm{U}-{ }^{14} \mathrm{C}\right.$ ]glutamic acid (specific activity $225 \mathrm{mCi} \mathrm{mmol}^{-1}$, purity $98 \%$ by paper chromatography) was obtained from ICN Radiochemicals (USA). [U- ${ }^{14} \mathrm{C}$ ]alanine, $\left[\mathrm{U}-{ }^{14} \mathrm{C}\right]$ lysine, $\left[\mathrm{U}-{ }^{14} \mathrm{C}\right]$ glycine and $\left[\mathrm{U}-{ }^{14} \mathrm{C} /\right.$ serine $(168,355,113$ and $169 \mathrm{mCi} \mathrm{mmol}^{-1}$, respectively, purity $>99 \%$ by high performance cation-exchange chromatography) were purchased from New England Nuclear (USA). The injected solutions also contained ${ }^{3} \mathrm{H}_{2} \mathrm{O}$, at about the same total radioactivity as the amino acids. ${ }^{3} \mathrm{H}_{2} \mathrm{O}$ was used to check that the interstitial water was completely homogenized by the mixing procedure.

Syringes were incubated in the dark at in situ temperature. After incubation, the contents of the syringes were extruded into $50 \mathrm{ml}$ conical centrifuge tubes, hornogenized with a Maxi Mix vortex mixer, and centrifuged at $1400 \times g$ for $7 \mathrm{~min}$ at $-1^{\circ} \mathrm{C}$. Thorough mixing of the sediment was essential to ensure that the small porewater volume containing the radiolabel was represented in the porewater sample recovered. After centrifuging, the porewater was pipetted off and filtered through a precombusted Whatman GF/F filter. One $\mathrm{ml}$ of porewater was placed in a scintillation vial, acidified, and the ${ }^{14} \mathrm{CO}_{2}$ collected on a wick containing $200 \mu \mathrm{l}$ of $\beta$-phenethylamine that was suspended over the sample. The remaining interstitial water was stored frozen until analysis for amino acid concentrations and specific activity by HPLC (high performance liquid chromatography).

The sediment 'pellet', still containing about $70 \%$ of its original water, was mixed with $10 \mathrm{ml}$ of glassdistilled water and $2 \mathrm{ml}$ of $5 \mathrm{~N} \mathrm{H}_{2} \mathrm{SO}_{4}$. Nitrogen was bubbled through this slurry for $15 \mathrm{~min}$, and the ${ }^{14} \mathrm{CO}_{2}$ stripped was trapped in $15 \mathrm{ml}$ of Woeller's solution for scintillation counting. Recoveries of $\left[{ }^{14} \mathrm{C}\right]$ bicarbonate standards added to sediment using this procedure were $93 \pm 3 \%$ (mean \pm 1 SD) (Doyle 1988). To check for losses of ${ }^{14} \mathrm{CO}_{2}$, a ${ }^{14} \mathrm{C}$-labeled bicarbonate solution was injected into sediment-filled syringes, which were then incubated. The average rate of ${ }^{14} \mathrm{CO}_{2}$ loss was only $0.65 \% \mathrm{~d}^{-1}$ (Doyle 1988).

After 4 to $6 \mathrm{~h}$ the acid-mud slurry $\left(0.6 \mathrm{~N} \mathrm{H}_{2} \mathrm{SO}_{4}\right)$ was centrifuged and the acid supernatant removed. Two $\mathrm{ml}$ of the supernatant was counted to determine total acid-soluble radioactivity, and the remainder was stored frozen for amino acid analysis. The sediment pellet was also frozen until the residual radioactivity in selected samples was measured. Acid-extracted sediments were rinsed twice with distilled water to remove the remaining acid solution and dried at $105^{\circ} \mathrm{C}$ overnight. Two grams of dried sediment were combusted in a Harvey Biological Oxidizer, and the ${ }^{14} \mathrm{CO}_{2}$ evolved was trapped in Woeller's solution for scintillation counting.

After selected incubation times, duplicate sediment subsamples were mixed for $10 \mathrm{~min}$ with $5 \mathrm{ml}$ of a $10 \mathrm{mM}$ seawater solution of the same (but not radiolabeled) amino acid added initially. The sediment slurry was centrifuged and the dissolved radioactivity measured in the supernatant. Subsequently, these sediments were treated as described above. The purpose of this treatment was to extract any adsorbed, exchangeable amino acid. Increasing the reaction time did not significantly increase the amount of activity recovered by ion exchange (Henrichs \& Sugai in press).

The percent of the injected radioactivity found in porewater was calculated based on the initial volume of water in each syringe, calculated by multiplying the sediment wet weight times the average water content. Acid extract solution activities were corrected for 
the radioactivity in porewater which remained after centrifugation. ${ }^{14} \mathrm{CO}_{2}$ data presented are the sum of radioactivity recovered in the porewater and by stripping the mud after acidification.

Killed controls. In 1986 killed control experiments were performed by autoclaving sediment-filled incubation syringes at $120^{\circ} \mathrm{C}$ for $10 \mathrm{~min}$. Sediments were cooled to $8^{\circ} \mathrm{C}$ before injecting a radiolabeled amino acid. Additional sediment treatments were tested during September 1989: chilling in a seawater ice/ seawater bath at $-2{ }^{\circ} \mathrm{C}$, autoclaving for $15 \mathrm{~min}$, heating in an oven at 50 or $70^{\circ} \mathrm{C}$ for $1 \mathrm{~h}$, and injection of 0.14 or $0.028 \mathrm{ml}$ formalin. The treated syringes were kept at $8{ }^{\circ} \mathrm{C}$ overnight, then injected with a ${ }^{14} \mathrm{C}$-labeled alanine solution. The sediment in half of the syringes was extruded into centrifuge tubes and processed immediately; the remaining syringes were incubated at 8 to $9.5^{\circ} \mathrm{C}$ for 5 to $7 \mathrm{~h}$. Killed controls for glutamic acid and lysine were also done in 1989, using injection of $0.028 \mathrm{ml}$ formalin or heat treatment at $50^{\circ} \mathrm{C}$. After incubation, the sediment was processed as described for the uptake and mineralization experiments.

Tracer addition techniques. To examine the effects of the method of tracer addition on the rates of uptake and mineralization of lysine and alanine, experiments were conducted using sediment collected during October 1989. In the first method, the tracer was injected into sealed syringes as in 1986. In the second, the sediment in the syringe was extruded into a $50 \mathrm{ml}$ centrifuge tube which was being flushed with argon. Ten $\mu$ l of the tracer solution was injected into the sediment with a microliter pipette and the sediment immediately homogenized for 1 min using a Maxi Mix. This mixing procedure was tested by adding ${ }^{3} \mathrm{H}_{2} \mathrm{O}$ to the sediment and was found to effectively homogenize the distribution of tracer in porewater. The third method of tracer addition was to add $20 \mu \mathrm{l}$ of the alanine or lysine tracer solution to $10 \mathrm{ml}$ of argon-stripped seawater containing $1 \mu \mathrm{M}$ alanine or $0.1 \mu \mathrm{M}$ lysine. The seawater was mixed with sediment extruded from a syringe in an argon-flushed centrifuge tube. Slurrying with ${ }^{3} \mathrm{H}_{2} \mathrm{O}$-containing seawater showed that the added seawater and porewater were completely mixed by this technique. Separate syringes or tubes were prepared and incubated, in duplicate, for each time point. Incubations were terminated as previously described

High performance liquid chromatography. Filtered porewater was analyzed for dissolved free amino acids by HPLC of their o-phthaldialdehyde (OPA) derivatives with fluorescence detection (Jones et al. 1981). The $\mathrm{pH}$ of $2 \mathrm{ml}$ of porewater was adjusted to 9.5 with a $0.4 \mathrm{M}$ borate buffer, $\alpha$-aminoadipic acid was added as an internal standard, and the derivatives were formed by addition of $50 \mu \mathrm{l}$ of reagent solution $(50 \mathrm{mg}$ OPA, $100 \mathrm{mg}$ lauryl sulfate and $50 \mu \mathrm{l}$ mercaptoethanol in
$5 \mathrm{ml}$ methanol). After $2 \mathrm{~min}, 1 \mathrm{ml}$ of the sample was injected into the liquid chromatograph. Amino acids were eluted from the Hamilton PRP-1 column in $40 \mathrm{~min}$ with a solvent gradient from $80 \% 0.025 \mathrm{M}$ phosphate buffer ( $\mathrm{pH} 6.5$ ) and $20 \%$ methanol to $20 \%$ buffer and

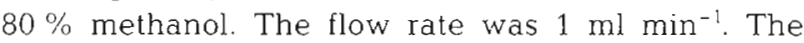
relative standard deviation of amino acid concentrations in standards run on the same days as the samples were $1 \%$ (glutamic acid), $4 \%$ (serine and glycine), $5 \%$ (alanine) and $11 \%$ (lysine).

A fraction collector distributed the effluent from the detector into vials at time intervals chosen to isolate the peaks of interest. Activity in the effuent was measured by scintillation counting. Collected activities were corrected for the recovery of ${ }^{14} \mathrm{C}$-labeled amino acid standards, $80 \pm 5 \%$.

Because the lysine derivative co-elutes with ammonia, interstitial water samples from lysine experiments were stripped to drive off ammonia. The $\mathrm{pH}$ was adjusted to 9.5 with borate buffer and the sample was bubbled with argon at $38^{\circ} \mathrm{C}$ for $30 \mathrm{~min}$. Samples were cooled to room temperature before adding the OPA reagent. This procedure has been checked by standard addition and by comparison of measured concentrations of amino acids other than lysine before and after ammonia stripping; the treatment does not cause changes in the amino acid concentrations measured.

Acid extract samples were also analyzed by HPLC. Before addition of OPA reagent, the samples were neutralized with sodium hydroxide solution, resulting in formation of a precipitate which was removed by centrifugation. Recovery checks showed that no amino acids were removed in the precipitate (Doyle 1988)

\section{RESULTS}

\section{Amino acid uptake and mineralization}

Fig. 1 presents results of uptake and mineralization experiments. All 5 added, radiolabeled amino acids disappeared from solution rapidly. Of the dissolved radioactivity remaining at 10 to $13 \mathrm{~min}, 90 \%$ or more was associated with the original amino acid for alanine, glutamic acid, glycine, and serine, but only $33 \%$ for lysine (Fig. 2). Excepting lysine, a substantial proportion of the remaining dissolved organic radioactivity was also the added amino acid at later time points; however, this was only a few percent of the radioactivity injected.

${ }^{14} \mathrm{CO}_{2}$ production was slower than the loss of labeled amino acids from solution and continued after dissolved, non- ${ }^{14} \mathrm{CO}_{2}$ activity had decreased to low, constant values (Fig. 1). Within 2 to $4 \mathrm{~h}, 40$ to $50 \%$ of alanine, glycine and serine was mineralized to ${ }^{14} \mathrm{CO}_{2}$. 

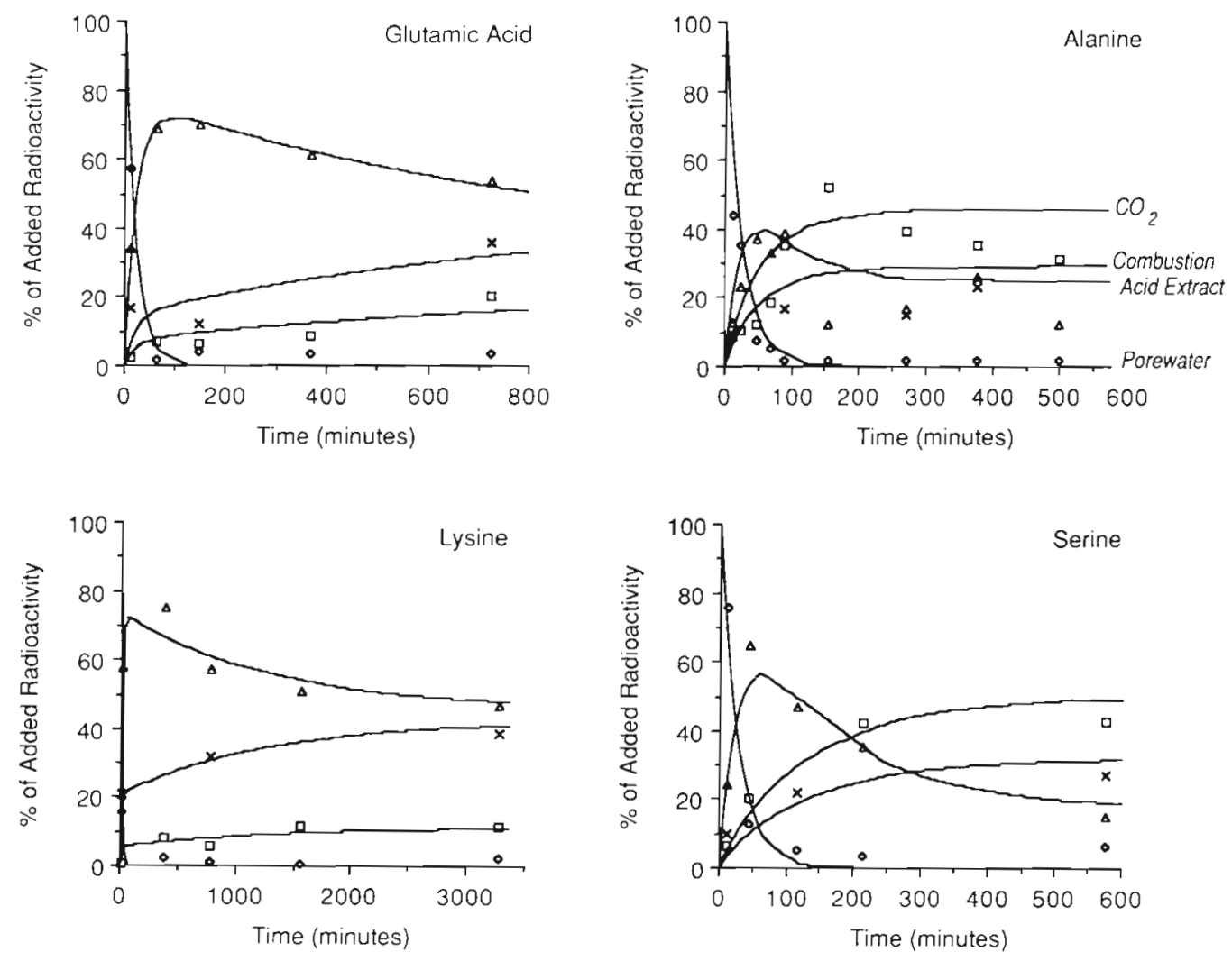

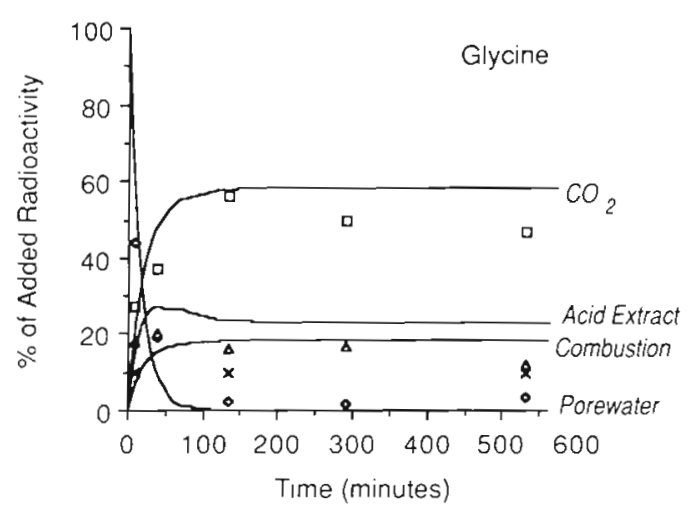

There was no additional mineralization of these amino acids between 4 and $8 \mathrm{~h}$. Only $17 \%$ of the glutamic acid was mineralized in $12 \mathrm{~h}$ and $11 \%$ of the lysine in $54 \mathrm{~h}$. Mineralization of these 2 amino acids was more rapid initially, but continued at a slow rate throughout the experiment.

A substantial fraction of the added radioactivity was extractable by $0.6 \mathrm{~N}$ acid at all time points and for all amino acids (Fig. 1). The acid-extractable fraction was larger for lysine and glutamic acid than for serine, alanine and glycine. The acid-extractable fraction increased to a maximum during the period of rapid decrease in dissolved radioactivity, then decreased. HPLC showed that radioactivity in the acid-extractable fraction consisted almost entirely of the added, labeled

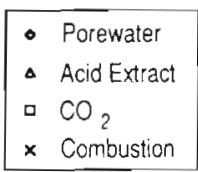

Fig. 1 Percent of injected activity in porewater, acid-extractable, $\mathrm{CO}_{2}$ and combustionrecovered fractions as a function of time following injection of the radiolabeled amino acid tracer. Lines were calculated using a model of the data described in the text and in Table 4 and the parameters given in Table 5 (total activity data)

amino acid at the first time point (Fig. 2). Subsequently, the amino acid fraction of the acid-extractable radioactivity decreased, but remained relatively high for glutamic acid and lysine. Substantial alanine and serine remained in the acid-extractable fraction, but no glycine was detected.

At 10 to $13 \mathrm{~min}$, a rinse with $10 \mathrm{mM}$ non-labeled amino acid in seawater recovered more dissolved alanine, lysine and glycine radioactivity than was recovered in porewater. For glycine, serine and alanine, $80 \%$ of the added radioactivity was recovered in the $10 \mathrm{mM}$ rinse, and for lysine and glutamic acid, $60 \%$. At the last time point the $10 \mathrm{mM}$ rinse recovered no dissolved organic radioactivity beyond the small amount still found in porewater. 

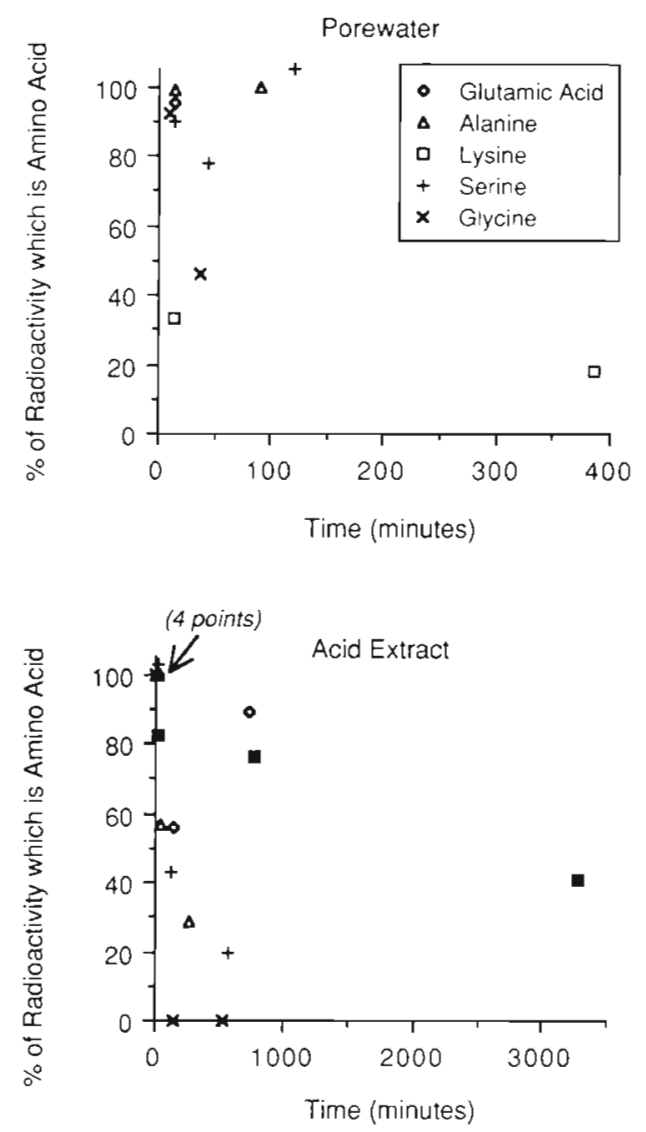

Fig. 2. Percent of the total radioactivity in porewaters or acid extracts of sediments which was the added amino acid at various incubation times. Porewater samples not analyzed by HPLC contained $\leq 6 \%$ of the added activity

The fraction of added radioactivity recoverable only by combustion increased with time, except in the case of glycine (Fig. 1). About $10 \%$ of the added alanine, serine and glycine radioactivity remained with the acid-extracted sediment residue after $10 \mathrm{~min}$. This initial fraction was larger for lysine and glutamic acid (21 and $17 \%$ ). The sum of the radioactivity recovered in porewater, acid extract, $\mathrm{CO}_{2}$ and combustion fractions averaged $92 \pm 12 \%$ of the added radioactivity.

Fig. 3a, b compares the results of uptake and mineralization experiments which used 3 different methods of introducing radiolabeled solution alanine and lysine: injection, injection with homogenization, and slurrying. The injected tracer results of these 1989 experiments were very similar to the 1986 results shown in Fig. 1. For alanine (Fig. 3a), the major difference between the 3 radiotracer addition methods was that the porewater radioactivity was greater after the shortest slurry incubation, and the acid-extractable radioactivity was correspondingly smaller. The ultimate ${ }^{14} \mathrm{CO}_{2}$ production was greater in the injected-tracer experiment than in the homogenized and slurried sediments. For lysine (Fig. 3b), all methods of tracer addition gave much lower porewater and $\mathrm{CO}_{2}$ activities and much higher acid-extractable activities than were observed for alanine. There were no apparent differences between the results for different radiolabeled lysine addition techniques.

\section{Killed controls}

Mineralization of amino acids in autoclaved 1986 sediment was negligible. For serine and glycine, 90 to $100 \%$ of the radioactivity was found dissolved in interstitial water for both 10 min and $7 \mathrm{~h}$ incubations. Initially $82 \%$ of alanine was recovered in interstitial water, but only $63 \%$ after $7 \mathrm{~h}$. At $14 \mathrm{~min} 34 \%$ of the lysine was dissolved and at $50 \mathrm{~h}, 29 \%$. After $12 \mathrm{~min}$ $92 \%$ of the glutamic acid tracer remained in solution; unfortunately, the $12 \mathrm{~h}$ sample was lost. Autoclaving caused a large increase in porewater amino acid concentrations (Table 1).

In 1989, alanine uptake and mineralization were compared in untreated, autoclaved, chilled $\left(-2^{\circ} \mathrm{C}\right)$, and heated $\left(70^{\circ} \mathrm{C}\right)$ sediments. No alanine mineralization $\left({ }^{14} \mathrm{CO}_{2}\right.$ production) occurred in either autoclaved or heated sediments, but alanine uptake and mineralization did not decrease in chilled sediments compared to those incubated at $8^{\circ} \mathrm{C}$. Also, 2 formalin and 2 heat treatments were evaluated for alanine (Fig. 4). All effectively eliminated ${ }^{14} \mathrm{CO}_{2}$ production over a 5 to $7 \mathrm{~h}$ incubation. Killed controls showed significant alanine (average of $20 \%$ ), glutamic acid (average of $30 \%$ ) and lysine (average of $82 \%$ ) adsorption (Fig. 4). After $0.2 \mathrm{~h}$ all of the adsorbed glutamic acid and alanine were recovered in the acid extract, but 10 to $20 \%$ of the added lysine was not recovered in either porewater or the acid extract. In formalin-treated sediments adsorption increased with time, and the recovery of lysine in the acid extract decreased, but this did not occur in heat-treated sediments.

Concentrations of amino acids in the 1989 killed control sediments are shown in Table 2. As before, autoclaving caused a large increase in all amino acid concentrations. Heating at 50 and $70^{\circ} \mathrm{C}$ also increased porewater amino acid concentrations. Porewater amino acid concentrations in formalin-treated sediments were similar to those in untreated sediments.

\section{Porewater amino acid concentrations}

The dissolved free amino acid (DFAA) concentrations in porewaters are shown in Table 1. Glutamic acid concentrations were greatest at about $1 \mu \mathrm{M}$. Alanine, 
a Alanine
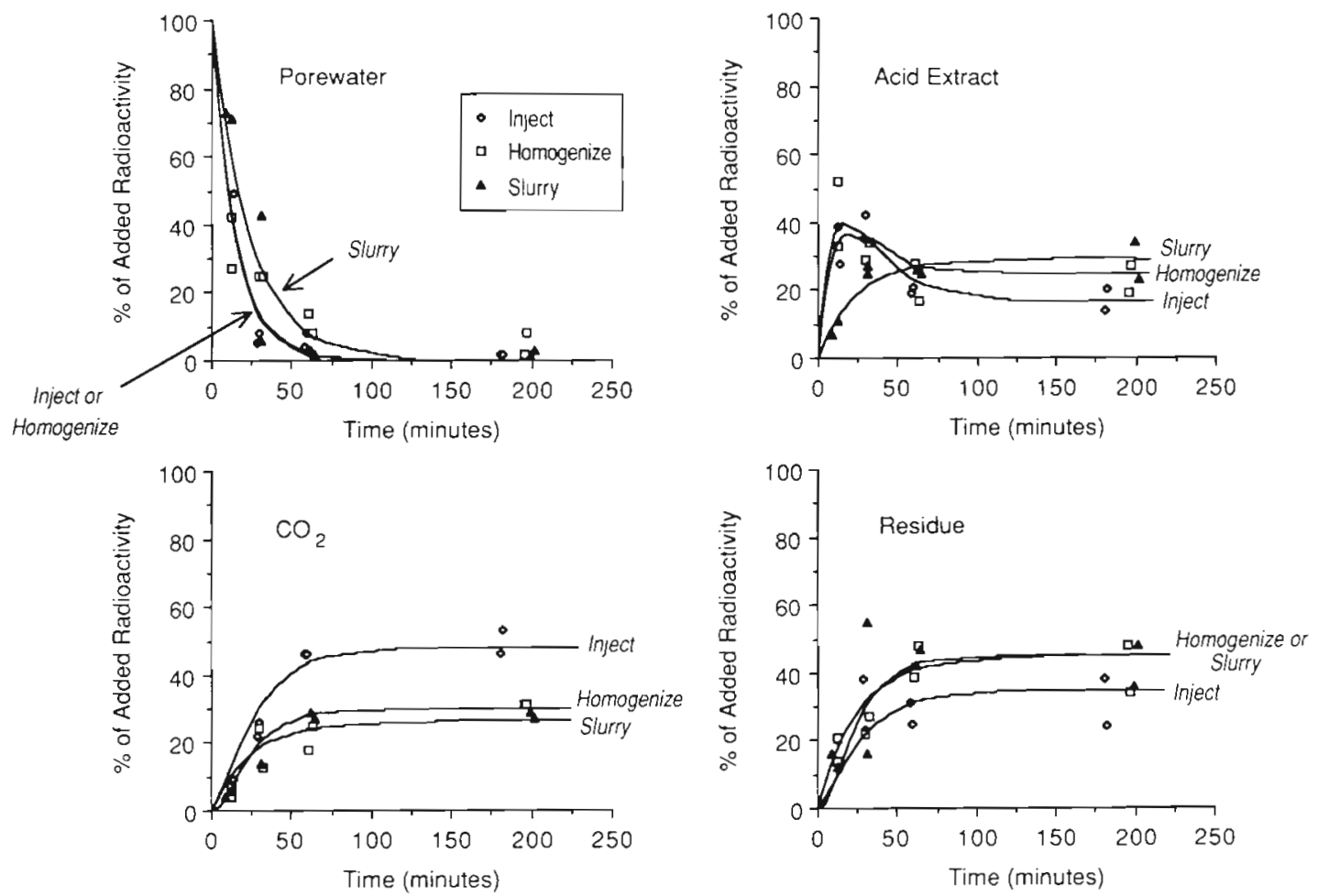

b Lysine
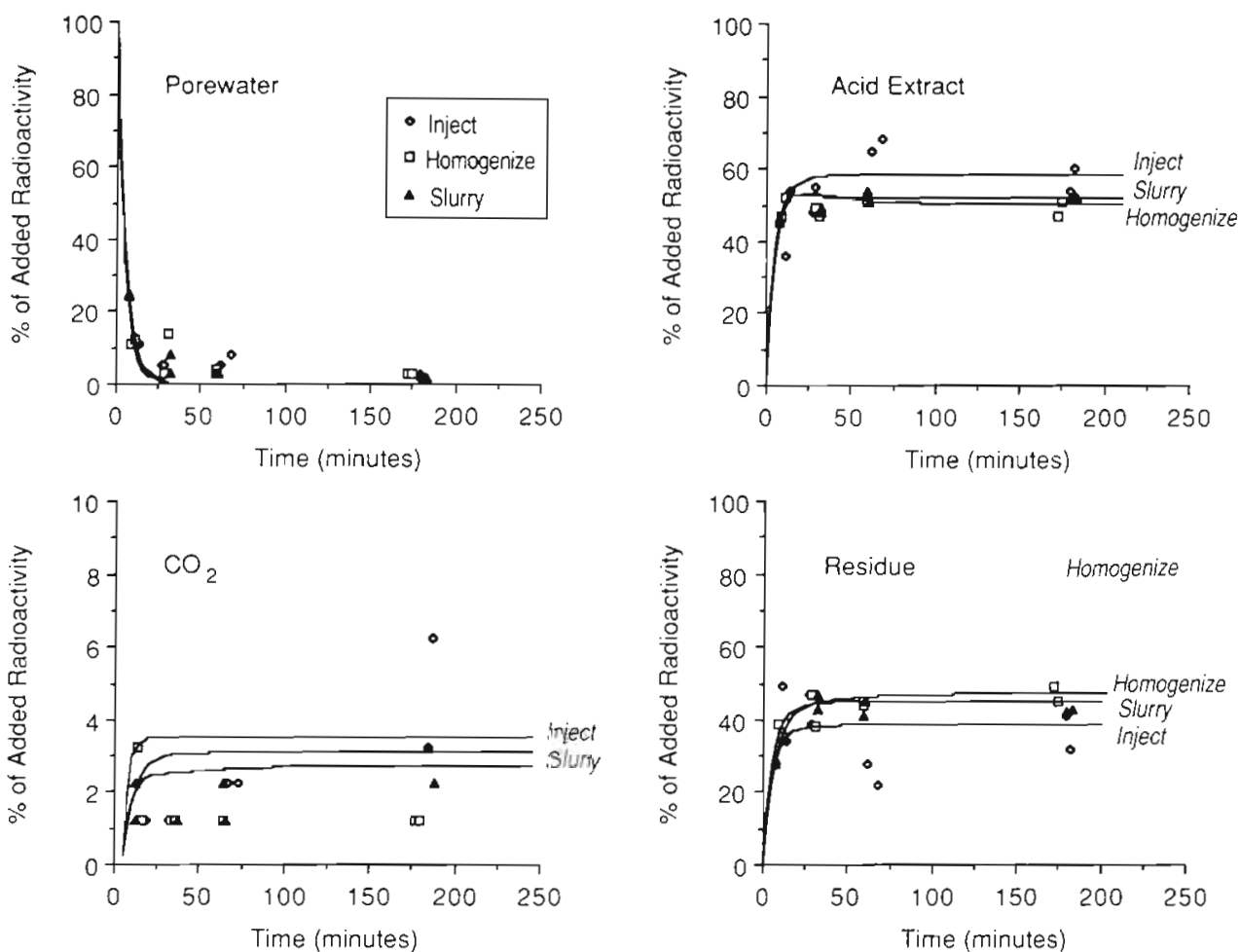

Fig. 3. Effects of radiotracer addition technique on decomposition and adsorption of (a) alanine and (b) lysine. The 'residue' was calculated by subtracting the total of the porewater, acid extract and $\mathrm{CO}_{2}$ from the added radioactivity, and was assumed to be equal to the amount of radioactivity recoverable by combustion of acid-extracted sediment. Lines were calculated using a model of the data described in the text and in Table 4 and the parameters given in Table 5 
Table 1. Amino acid concentrations in porewaters and acid extracts from 1986 sediment samples

\begin{tabular}{|c|c|c|c|c|c|c|}
\hline \multirow{2}{*}{ Amino acid } & \multirow{2}{*}{$\begin{array}{l}\text { Time } \\
(\text { min })^{d}\end{array}$} & \multicolumn{4}{|c|}{ Porewater } & \multirow{2}{*}{$\begin{array}{c}\text { Acid } \\
\text { extract } \\
\left(\mathrm{nmol} g^{\prime}\right)^{b}\end{array}$} \\
\hline & & $\begin{array}{l}\text { Unt } \\
(\mu \mathrm{M})\end{array}$ & $\begin{array}{l}\text { d sediment } \\
\left(\text { nmol } g^{-1}\right)^{b}\end{array}$ & $\begin{array}{l}\text { Autc } \\
(\mu \mathrm{M})\end{array}$ & $\begin{array}{l}\text { ed sediment } \\
\left(n m o l g^{-1}\right)^{i}\end{array}$ & \\
\hline \multirow[t]{3}{*}{ Glutamic acid } & 13 & 0.83 & 0.33 & 22 & 8.8 & 8.0 \\
\hline & 147 & 0.95 & 0.40 & - & - & 4.3 \\
\hline & 724 & - & - & - & - & 8.8 \\
\hline \multirow[t]{4}{*}{ Alanine } & 13 & 0.09 & 0.04 & 9.7 & 3.9 & 2.8 \\
\hline & 45 & 0.12 & 0.05 & - & - & - \\
\hline & 88 & 0.05 & 0.02 & - & - & 2.1 \\
\hline & 377 & - & - & 13 & 5.2 & 2.2 \\
\hline \multirow[t]{4}{*}{ Lysine } & 13 & 0.09 & 0.04 & 1.5 & 0.6 & 0.2 \\
\hline & 387 & 0.06 & 0.02 & - & - & - \\
\hline & 775 & 0.01 & 0.004 & - & - & 5.8 \\
\hline & 3275 & - & - & 1.8 & 0.7 & 0.2 \\
\hline \multirow[t]{4}{*}{ Serine } & 13 & 0.05 & 0.02 & 2.7 & 1.1 & 2.6 \\
\hline & 45 & 0.04 & 0.02 & - & - & - \\
\hline & 117 & 0.05 & 0.02 & - & - & 0.1 \\
\hline & 575 & - & - & 2.2 & 0.88 & 2.9 \\
\hline \multirow[t]{4}{*}{ Glycine } & 10 & 0.08 & 0.03 & 10 & 4.0 & 1.4 \\
\hline & 38 & 0.10 & 0.04 & - & - & - \\
\hline & 135 & 0.33 & 0.13 & - & - & 14 \\
\hline & 533 & - & - & 5.6 & 2.2 & 0.6 \\
\hline
\end{tabular}

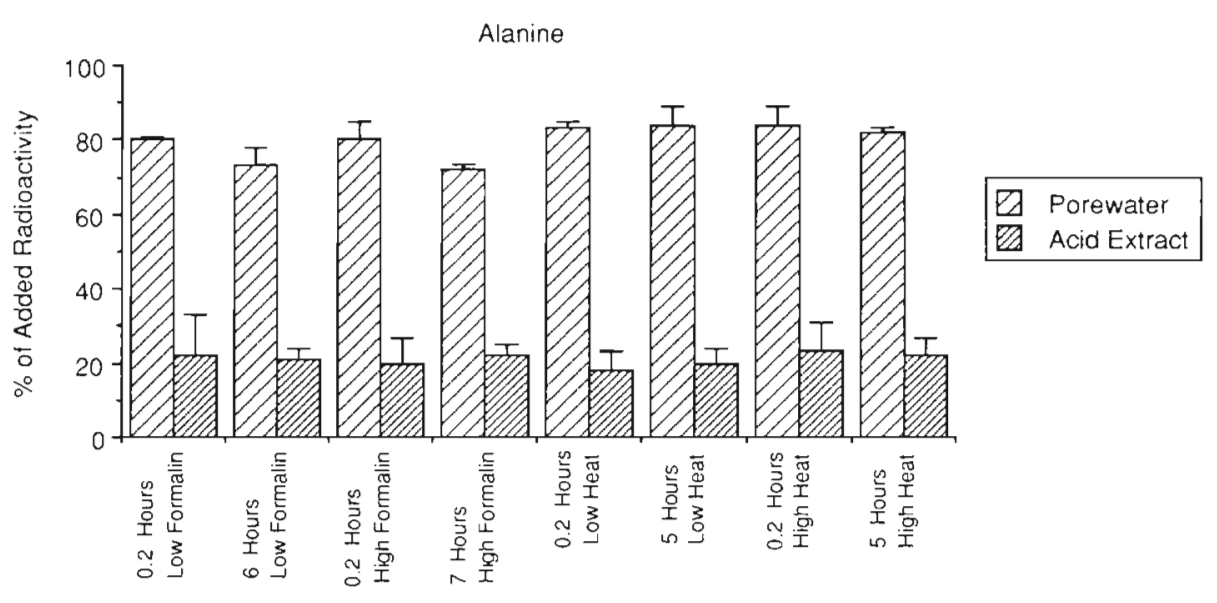

Fig, 4. Fate of radioactivity added to killed control sediments. No ${ }^{14} \mathrm{CO}_{2}$ (above blank) was recovered from any of these sediments. Data shown are the mean of 3 replicates. Error bars $=1 \mathrm{SD}$. Times given in the $x$-axis labels are the incubation times between addition of radiotracer and filtering of the porewater sample. Treatments shown along the $x$ axis are: High Formalin = injection of $0.14 \mathrm{ml}$ formalin into the syringe at least $12 \mathrm{~h}$ before injection of the radiolabeled amino acid; Low Formalin = injection of $0.028 \mathrm{ml}$ of formalin; High Heat $=$ heating in an oven at $70^{\circ} \mathrm{C}$ for $1 \mathrm{~h}$; Low Heat $=$ heating at $50^{\circ} \mathrm{C}$
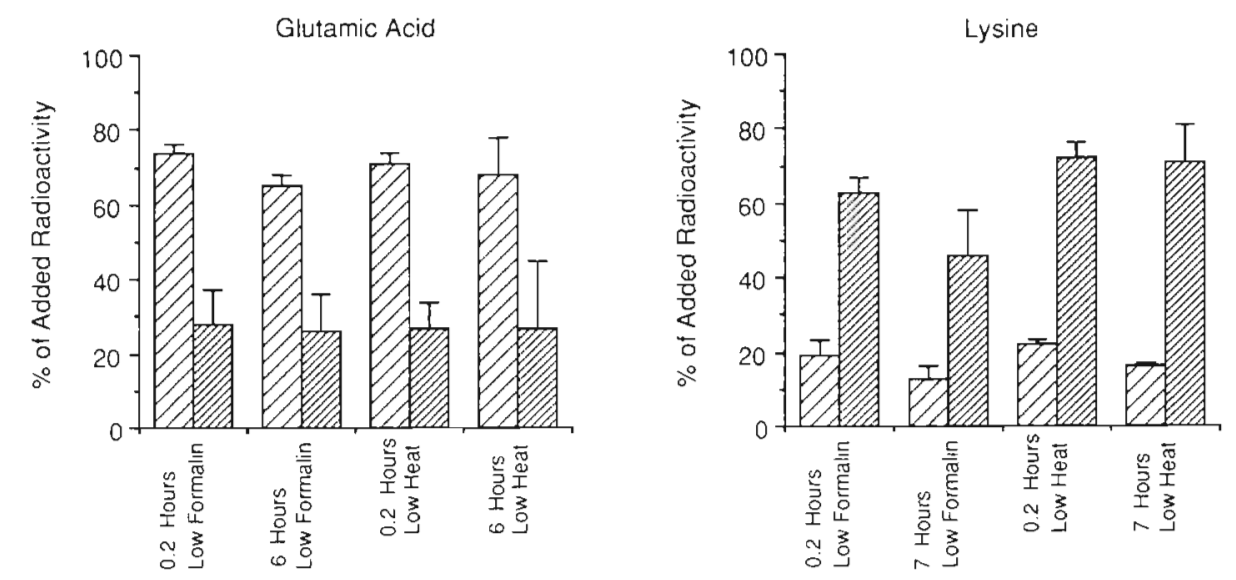
Table 2. Amino acid concentrations in porewaters of 1989 killed control experiments. n: no. of replicates analyzed. Data are given as mean $\pm \mathrm{SD}$

\begin{tabular}{|c|c|c|c|c|c|c|}
\hline \multirow[t]{2}{*}{ Treatment } & \multirow[t]{2}{*}{ Date } & \multicolumn{5}{|c|}{ Amino acid concentration $(\mu \mathrm{M})$} \\
\hline & & Glutamic acid & Alanine & Lysine & Serine & Glycine \\
\hline $\begin{array}{l}\text { Autoclave } \\
(n=5)\end{array}$ & $6 \mathrm{Sep}$ & $5 \pm 2$ & $7 \pm 4$ & $4 \pm 4^{c}$ & $3.2 \pm 0.5$ & $10 \pm 1$ \\
\hline $\begin{array}{l}\text { Heat, } 70^{\circ} \mathrm{C} \\
(\mathrm{n}=6)\end{array}$ & $6 \mathrm{Sep}$ & $3 \pm 2$ & $22 \pm 9$ & $2^{c}$ & $2.9 \pm 0.7$ & $11 \pm 2$ \\
\hline Low Formalin & 26 Sep & $\begin{array}{c}1.0 \pm 0.3 \\
(\mathrm{n}=9)\end{array}$ & $\begin{array}{c}0.7 \pm 0.8 \\
(\mathrm{n}=9)\end{array}$ & $\mathrm{ND}^{\mathrm{c}}$ & $\begin{array}{c}0.4 \pm 0.2 \\
(\mathrm{n}=5)\end{array}$ & $\begin{array}{l}1 \pm 1 \\
(\mathrm{n}=3)\end{array}$ \\
\hline $\begin{array}{l}\text { Heat, } 70^{\circ} \mathrm{C} \\
(\mathrm{n}=4)^{\mathrm{a}}\end{array}$ & $26 \mathrm{Sep}$ & $14 \pm 2$ & $11 \pm 2$ & $0.7 \pm 0.1^{c}$ & $6 \pm 1$ & $13 \pm 4$ \\
\hline $\begin{array}{l}\text { Heat, } 50^{\circ} \mathrm{C} \\
(\mathrm{n}=15)^{\mathrm{a}}\end{array}$ & 26 Sep & $4 \pm 3$ & $9 \pm 5$ & $0.4 \pm 0.2^{c}$ & $1.6 \pm 0.6$ & $7 \pm 3$ \\
\hline $\begin{array}{l}\text { Untreated } \\
\text { sediment }\end{array}$ & & $3.7 \pm 0.7$ & $1.6 \pm 0.5$ & $0.1 \pm 0.1$ & $0.4 \pm 0.2$ & $2.8 \pm 1.5^{d}$ \\
\hline \multicolumn{7}{|c|}{$\begin{array}{l}\text { "One additional sample was analyzed, but was omitted from the means shown because its amino acid concentration was } \\
\text { about an order of magnitude greater than the other concentrations } \\
\text { Data from Table } 3 \\
\text { "Because stripping of samples was required for lysine analysis, fewer replicates were analyzed: } \mathrm{n}=2, \mathrm{n}=1, \mathrm{n}=0 \text { (ND=not } \\
\text { determined), } \mathrm{n}=2 \text { and } \mathrm{n}=10 \text { for the } 5 \text { treatments listed } \\
\text { d Glycine + threonine concentration }\end{array}$} \\
\hline
\end{tabular}

serine, glycine and lysine concentrations were similar $(0.08 \pm 0.04 \mu \mathrm{M})$ in most porewater samples. Concentrations in the acid extracts were much greater than in porewaters and were highly variable for glycine, lysine and serine. One possible explanation for this variability is the non-uniform numbers of macrofauna trapped in the syringes.

The effect of centrifuging times and speeds on extracted porewater amino acid concentrations is shown in Table 3. Concentrations and compositions of amino acids in porewaters extracted by centrifuging at $460 \times g$ for $8 \mathrm{~min}$ and at $1400 \times g$ for 4 and $16 \mathrm{~min}$ did not differ from those of porewaters extracted under the 'standard' conditions, $1400 \times g$ for 8 min.

\section{DISCUSSION}

\section{Killed controls and adsorption}

Obtaining accurate data on adsorption of amino acids by sediments is difficult because any treatment used to eliminate biological activity can also affect chemical processes of adsorption. Autoclaving and heating at 50 or $70^{\circ} \mathrm{C}$ cause similar, marked increases in porewater amino acid concentrations (Tables 1 \& 2). In sediments the adsorbed/dissolved ratio of amino acids decreases with increasing dissolved amino acid concentration (Henrichs \& Farrington 1987, Henrichs \& Sugai in press). Thus, these types of controls could

Table 3. Effect of centrifuging time and speed (centrifugal force) on porewater amino acid concentrations ( $\mu \mathrm{M}$ ) Values are the mean of 2 replicates, except for the $8 \mathrm{~min}, 1400 \times g$ conditions where there were 6 replicates. Data are given as mean \pm 1 SD

\begin{tabular}{|c|c|c|c|c|}
\hline Amino acid & $\underset{1400 \times g}{4 \min }$ & $\begin{array}{c}8 \mathrm{~min} \\
1400 \times \mathrm{g}\end{array}$ & $\begin{array}{c}8 \mathrm{~min} \\
460 \times g\end{array}$ & $\begin{array}{c}16 \mathrm{~min} \\
1400 \times \mathrm{g}\end{array}$ \\
\hline Glutamic acid & $4.2 \pm 0.1$ & $3.7 \pm 0.7$ & $3.9 \pm 0.6$ & $3.7 \pm 0.2$ \\
\hline Alanine & $1.7 \pm 0.1$ & $1.6 \pm 0.5$ & $2.0 \pm 0.3$ & $1.4 \pm 0.05$ \\
\hline Lysine & $0.06 \pm 0.007$ & $0.1 \pm 0.1$ & $0.15 \pm 0.07$ & $0.06 \pm 0.007$ \\
\hline Serine & $0.4 \pm 0.07$ & $0.4 \pm 0.2$ & $0.4 \pm 0.0$ & $0.4 \pm 0.3$ \\
\hline Glycine + threanine & $3.5 \pm 0.8$ & $2.8 \pm 1.5$ & $5.3 \pm 1.4$ & $1.9 \pm 0.4$ \\
\hline Total ${ }^{\circ}$ & $21 \pm 2$ & $19 \pm 5$ & $22 \pm 0.4$ & $16 \pm 2$ \\
\hline
\end{tabular}


underestimate adsorption. Formalin does not have a large effect on porewater amino acid concentration, but formaldehyde is a very reactive molecule which can bind to the amino groups of amino acids. However, heat- and formalin-treated controls gave very similar adsorption results (Fig. 4). Probably, effects of concentration differences were minimized because the concentrations were within a range over which $\%$ adsorption of glutamic acid, alanine, and lysine by Resurrection Bay sediments is reasonably constant (Henrichs \& Sugai in press). Consistency in the extent of adsorption between heat- and formalin-treated controls, and between these controls and the behavior of amino acids in uptake and mineralization experiments, indicates that the controls provide a useful estimate of adsorption in Resurrection Bay sediments. However, these controls should not be used elsewhere without evaluation. Particularly, treatment effects on porewater amino acid concentration and concentration effects on adsorption should be checked.

The fraction adsorbed in the heated controls did not change between 0.2 and 5 to $7 \mathrm{~h}$, indicating that adsorption is a rapid process. There was a small increase in adsorption in formalin-treated sediments over time, but this is probably an artifact caused by the formalin.

Other studies of amino acid adsorption have been done with Resurrection Bay sediments (Doyle 1988, Henrichs \& Sugai in press) and other sediments or minerals (Christensen \& Blackburn 1980, Hedges \& Hare 1987, Henrichs \& Farrington 1987). The adsorption of basic amino acids, such as lysine, has usually been substantially greater than that of acidic and neutral amino acids. The same pattern was found in this study (Fig. 4).

Concentrated amino acid solutions $(10 \mathrm{mM})$ added immediately after injection of the radiolabeled amino acid into biologically-active sediments recovered no additional radioactivity beyond that in porewater for glutamic acid and serine, about half of the particlebound alanine and lysine, and two-thirds of the glycine. The radioactivity not recovered was greatest, $40 \%$ of added radioactivity, for lysine and glutamic acid, and about $20 \%$ for alanine, glycine and serine. Although biological availability is not necessarily directly related to exchangeability, glutamic acid and lysine, with larger initial unexchanged fractions, had lower rates of amino acid respiration (Fig. 1).

\section{Techniques of introducing the radiolabeled amino acids}

The injection technique for introducing radiolabeled amino acids into sediments was chosen because it results in minimal sediment disturbance (Jørgensen 1978,
Meyer-Reil 1986, Dobbs et al. 1989). Slurrying sediments with seawater can increase rates of incorporation of dissolved organic substances (Meyer-Reil 1986) and decrease rates of sulfate reduction (Jørgensen 1978. Burdige 1989) and ammonium production (Burdige 1989). The injection technique does have potential disadvantages. The concentration of the injected amino acid solution, about $5 \mu \mathrm{M}$, is 5 (for glutamic acid) to 50 (for lysine) times greater than the porewater amino acid concentration. Also, with the injection technique the tracer is not uniformly distributed in the sediment. In the 'slurried' and 'homogenized' sediments, the specific activity of the amino acids in porewater is initially uniform throughout the sediment sample, and porewater amino acid concentrations are increased less than $10 \%$ by the radiolabeled amino acid.

However, the results of the 3 radiotracer introduction techniques were quite similar. The variation in ${ }^{14} \mathrm{CO}_{2}$ production with the $3\left[{ }^{14} \mathrm{C}\right.$ alanine addition techniques is about the same as the variability observed when using the injection technique alone. In 1985 a series of replicate alanine uptake and mineralization experiments in Resurrection Bay sediments found that $36 \pm 9 \%(n=8)$ of injected alanine was respired to ${ }^{14} \mathrm{CO}_{2}$ in $1.3 \mathrm{~h}$ and $41 \pm 7 \%$ in $5 \mathrm{~h}(\mathrm{n}=10)$ (Doyle 1988). The similarity in the results of the 3 radiotracer addition techniques is consistent with the observations of Christensen \& Blackburn (1980), who found that alanine uptake and mineralization rates measured by an injection technique were insensitive to the concentration and specific radioactivity of the injected amino acid solution. This is probably because, in practice, the dissolved amino acid concentrations in the radiolabeled portion of the sediment are about the same as in the rest of the sediment porewater soon after tracer injection. Injections of dye solutions into silica gel/water suspensions provide evidence that injected, radiolabeled amino acid solutions are rapidly diluted by mixing as the tracer is injected.

The one obvious difference in results of the different radiolabeled amino acid addition methods was that initial alanine porewater radioactivity in the slurried sediment was greater than in the homogenized or injected sediment, while the acid-extractable activity was correspondingly less. This could be due to biological effects of slurrying or the effect of sediment/solution ratio on adsorption. Adsorption, expressed as the \% of amino acid removed from solution, decreases with decreasing sediment/water ratios (Henrichs \& Farrington 1987).

\section{Biological uptake, adsorption, and mineralization of amino acids}

The following interpretation is proposed for the data in Figs. 1 through 4. Free amino acids are lost from the 
dissolved pool by 2 processes, uptake by bacteria and adsorption to sediment particles. Initially, the acidextractable fraction consists of adsorbed amino acids and free amino acids in intracellular pools of bacteria. At later times the acid-extractable fraction could inclucie intracellular or extracellular adsorbed amino acid metabolites or acid-soluble macromolecules (e.g. peptides, proteins or fulvic acids) in addition to the adsorbed amino acids. Some of the amino acids and other substances in the operationally-defined acidextractable pool are ultimately mineralized to ${ }^{14} \mathrm{CO}_{2}$. However, the acid-extractable fraction is heterogeneous and some of this material is not mineralized on time scales of hours to days. Possible explanations include inaccessibility of chemically-adsorbed compounds to bacteria or isotopic dilution of the tracer in large adsorbed or intracellular pools of the amino acid or metabolites. The fraction of added radioactivity recovered by combustion probably consists mostly of amino acids incorporated into bacterial cells. However, killed controls show that the acid-insoluble fraction also includes adsorbed lysine. Formation of refractory organic nitrogen during decomposition of estuarine macrophytes has been attributed to condensation reactions between amino acids and reactive carbohydrate and phenolic groups in the detrital organic material (Rice 1982). Henrichs \& Sugai (in press) present evidence that such condensation reactions occur in marine sediments.

The relative contribution of adsorbed and intracellular free amino acids to the acid-extractable pool can be estimated from data in Fig. 4. The killed controls indicate that adsorption can explain about half of the initial acid-extractable fraction for glutamic acid and alanine and nearly all of the acid-extractable fraction for lysine. Adsorption of glycine and serine was not evaluated in detail, but is less than alanine adsorption based on the autoclaved controls. Adsorption is thus as important as biological uptake in removing glutamic acid and alanine from solution and is the dominant process for lysine

\section{Rate calculations}

The equations used to calculate amino acid uptake and mineralization rates are given in Table 4 This model is based on certain assumptions and simplifications. The rate of biological uptake of radiolabeled substances is assumed to be first order with respect to tracer concentration (Eq. 1). Bacterial uptake of amino acids results in metabolism to ${ }^{14} \mathrm{CO}_{2}$, incorporation into an acid-extractable intracellular pool, or incorporation into insoluble biomass (Eqs. 2 \& 3). There is no evidence in the HPLC data for the accumulation of substantial amounts of non-amino acid radioactivity in porewaters, e.g. volatile fatty acids. Adsorption is not considered separately at this stage; both bacterial and adsorptive uptake from porewater to the acidextractable pool are combined in the term $k_{3} C_{P W}$ (Eq. 1). Since ${ }^{14} \mathrm{CO}_{2}$ production continues after porewater radioactivity is negligible, Eq. 3 provides for metabolism of a portion of the the acid-extractable pool. Mineralization of the acid-extractable pool, which could include adsorbed and intracellular amino acids or other compounds, is modeled simply with one rate constant, $k_{2}$. In order to fit the data, it is assumed that some of the acid-extractable pool, $C_{\mathrm{U}}$, is not mineralized on the time scales of this study. $C_{U}$ could represent adsorbed compounds which are not readily exchangeable nor metabolizable under conditions in the sediments. Alternatively, slow mineralization of $C_{U}$ tracer could be due to isotope dilution in a large intracellular or adsorbed amino acid pool.

Values for $k_{1}, k_{2}, k_{3}, C_{U}$, and $R$ (Table 5) were estimated by fitting Eqs. 4 to 6 to the porewater, acidextractable, $\mathrm{CO}_{2}$ and combustion-recovered radioactivity data simultaneously. Both total radioactivity and amino acid radioactivity (porewater and acidextractable activities corrected for the amino acid con-

Table 4. Model used in calculation of amino acid uptake, adsorption and mineralization rates

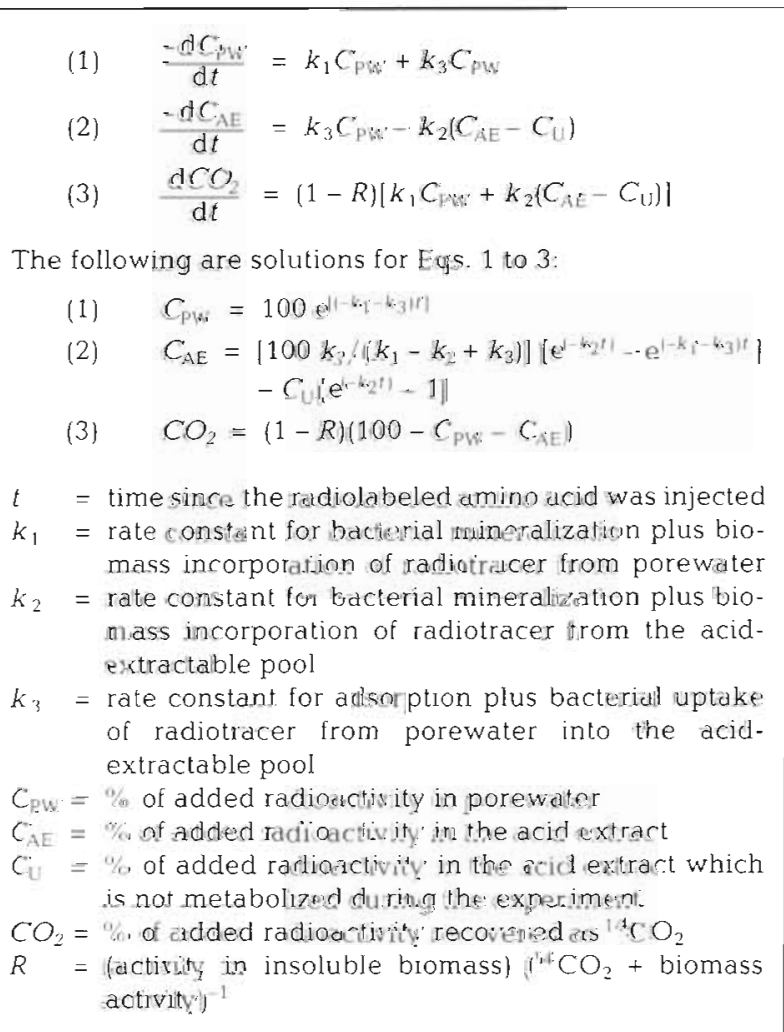


$C_{\mathrm{PW}} \cdot$ varied among syringes, so the concentrations from $t_{1}$ syringes, corresponding to the times when porewater radioactivity was decreasing rapidly, were used along with model parameters obtained for 1986 total radioactivity data (Table 5). The calculated mineralization rates were: 1 (alanine), 8 (glutamic acid), 3

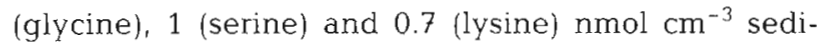
ment $\mathrm{d}^{-1}$, a total of $14 \mathrm{nmol} \mathrm{cm}^{-3}$ sediment $\mathrm{d}^{-1}$ for the 5 amino acids. (If the model parameters for amino acid radioactivity are used, the resulting total rate is similar, $11 \mathrm{nmol} \mathrm{cm}^{-3}$ sediment $\mathrm{d}^{-1}$.) Since glutamic acid. alanine, glycine, and serine make up about $80 \%$ of the total DFAA in porewaters, their total rate of mineralization is probably close to the total for all amino acids.

A much simpler approach to calculating the amino acid mineralization rate is to multiply the fraction of added radioactivity recovered as ${ }^{14} \mathrm{CO}_{2}$ at the first time point by $\phi C_{\mathrm{pw}} \%$ time. The resulting rates are 0.6 (alanine), 2 (glutamic acid), 2 (glycine), 0.2 (serine) and 0.07 (lysine) $\mathrm{nmol} \mathrm{cm} \mathrm{cm}^{-3}$ sediment $\mathrm{d}^{-1}$, a total of $5 \mathrm{nmol}$ $\mathrm{cm}^{-3}$ sediment $\mathrm{d}^{-1}$ for the 5 amino acids. Later time points cannot be used because of rapid removal of the tracer from porewater. This ${ }^{14} \mathrm{CO}_{2}$-based calculation underestimates rates because it neglects any mineralization which occurs slowly via intracellular amino acid or metabolite pools (King \& Klug 1982).

\section{Rate comparisons and critique}

The total organic nitrogen content of the Thumb Cove sediment is $0.07 \%$ of dry sediment weight (Henrichs \& Doyle 1986) or $50 \mu \mathrm{mol} \mathrm{N} \mathrm{cm}^{-3}$ sediment. The amino acid mineralization rate of $14 \mathrm{nmol} \mathrm{cm}^{-3}$ sediment $\mathrm{d}^{-1}$ is equivalent to mineralization of $5 \mu \mathrm{mol}$ $\mathrm{N} \mathrm{cm}^{-3}$ sediment $\mathrm{yr}^{-1}$ or about $10 \%$ of the total nitrogen per year.

The sediment ammonia production rate estimated from the porewater ammonia concentration profile (Henrichs \& Doyle 1986) and a 1-dimensional, steady state model described by Berner (1980) decreases sharply with depth. At 3 to $5 \mathrm{~cm}$ depth it is 1.4 to $0.21 \mathrm{nmol} \mathrm{cm}^{-3}$ sediment $\mathrm{d}^{-1}$. This is at least 10 times less than the total mineralization rate for the 5 amino acids studied, $14 \mathrm{nmol} \mathrm{cm}^{-3}$ sediment $\mathrm{d}^{-1}$. Because ammonia is a product of amino acid mineralization, these results appear inconsistent.

The nitrate maximum in this sediment occurs at 0 to $2 \mathrm{~cm}$ depth (Henrichs \& Doyle 1986), indicating that porewater oxygen is exhausted below this depth interval. Thus, ammonia oxidation is probably not significant at 4 to $5 \mathrm{~cm}$. Another possible explanation for the discrepancy is that the ammonia production rate estimated from the porewater profile is a net rate. Ammonia assimilation by bacteria would lead to an underestimate of the total rate, as would irreversible adsorption by sediments. Other studies of a variety of coastal and estuarine sediments, using ${ }^{15} \mathrm{NH}_{4}{ }^{+}$isotope techniques, found that the rate of ammonia assimilation ranged from 11 to $120 \%$ (mean $61 \pm 31 \%$ ) of the rate of production (Blackburn \& Henriksen 1983, Sumi $\&$ Koike 1990). Thus, the net ammonia production rate calculated here is probably a significant underestimate of gross production.

The difference between ammonia production and amino acid mineralization rates could also partly reflect uncertainty in the model parameters $k_{1}, k_{3}$, and $R$. This can be estimated from model results for the several decomposition experiments done using alanine and lysine (Table 5). The range of rates calculated using $\phi\left\{k_{1}+k_{3}\left[\left(C_{\mathrm{AEmax}}-C_{\mathrm{AEk} \text { Ill }}\right) / C_{\mathrm{AEmax}}\right]\right\} C_{\mathrm{PW}} \cdot(1-R)$ is 1.0 to $2.0 \mathrm{nmol} \mathrm{cm} \mathrm{cm}^{-3}$ sediment $\mathrm{d}^{-1}$ for alanine and 0.5 to $0.7 \mathrm{nmol} \mathrm{cm} \mathrm{cm}^{-3}$ sediment $\mathrm{d}^{-1}$ for lysine. Also, if adsorption was under-correcled in the model calculation, bacterial uptake rates would have been overestimated. However, the simple ${ }^{14} \mathrm{CO}_{2}$-based calculation gave a minumum estimate of mineralization which was only a factor of 3 less.

Another factor to be considered is the amino acid concentrations measured. The extraction procedure (centrifugation) could increase porewater concentrations, but the fact that concentrations were not affected by centrifuging speed or time makes this unlikely. There is, however, substantial small-horizontal-scale variability in amino acid concentrations, even within single box cores (Table 3 ). The relative standard deviation of the total amino acid concentration of 6 replicate samples, centrifuged under the conditions used in experiments, was $26 \%$.

A discrepancy between alanine mineralization and ammonia production rates in Limfjord sediments was also observed by Christensen \& Blackburn (1980). They proposed that, like acetate (Christensen \& Blackburn 1982, Parkes et al. 1984), alanine was complexed by macromolecules in porewater. This complexed alanine would be measured by the analytical technique used (HPLC of OPA derivatives) as free alanine, but would not be metabolized as rapidly. At the same time the Resurrection Bay work described here was conducted, experiments looking for evidence of refractory amino acid complexes in porewater were done (McDaniel 1989). No evidence for such complexes was found. The amino acids measured in extracted porewater using HPLC were taken up by bacteria just as rapidly as added, radiolabeled amino acids.

Thus, we cannot identify any reason to doubt the magnitude of the calculated amino acid mineralization rates. These rates indicate that a substantial fraction of total sediment nitrogen could be mineralized via dissolved free amino acids each year 
Acknowledgements. This work was supported by grants OCE-8516178 and OCE-8900362 from the National Science Foundation.

\section{LITERATURE CITED}

Alperin, M. J., Reeburgh, W. S. (1985). Inhibition experiments on anaerobic methane oxidation. Appl. environ. Microbiol. 50: 940-945

Berner, R. A. (1980). Early diagenesis: a theoretical approach. Princeton University Press, Princeton, NJ

Blackburn, T H., Henriksen, K. (1983). Nitrogen cycling in different types of sediments from Danish waters. Limnol. Oceanogr. 28: 477-493

Burdige, D. J. (1989). The effects of sediment slurrying on microbial processes and the role of amino acids as substrates for sulfate reduction in anoxic marine sediments. Biogeochem. 8: 1-23

Carlucci, A. F., Craven, D. B., Henrichs, S. M. (1984). Diel production and microheterotrophic utilization of dissolved free amino acids in waters off Southern California. Appl. environ. Microbiol. 48: 165-170

Christensen, D., Blackburn, T. H. (1980). Turnover of tracer $\left({ }^{14} \mathrm{C},{ }^{3} \mathrm{H}\right.$ labeled) alanine in inshore marine sediments. Mar. Biol. 58: 97-103

Christensen, D., Blackburn, T H. (1982). Turnover of ${ }^{14} \mathrm{C}$. labeled acetate in marine sediments. Mar. Biol. 71. $113-119$

Dobbs, F. C., Guckert, J. B., Carman, K. R. (1989). Comparison of three techniques for administering radiolabeled substrates to sediments for trophic studies: incorporation by microbes. Microb. Ecol. 17: 237-250

Doyle, A. P. (1988). Respiration and adsorption of alanine, glutamic acid, lysine, and glucose in sediments from Resurrection Bay, Alaska. M.S. thesis, University of Alaska, Fairbanks

Hedges, J. I., Hare, P. E. (1987). Amino acid adsorption by clay minerals in distilled water. Geochim. Cosmochim. Acta 51: 255-259

Henrichs, S. M., Doyle, A. P. (1986). Decomposition of ${ }^{14} \mathrm{C}-$ labeled organic substances in marine sediments. Limnol. Oceanogr. 31: 765-778

Henrichs, S. M., Farrington, J. W. (1987). Early diagenesis of amino acids and organic matter in two coastal marine sediments. Geochim. Cosmochim. Acta 51: 1-15

This article was presented by J. Fuhrman, Los Angeles, California, USA
Henrichs, S. M., Sugai, S. F. (in press). Adsorption of amino acids and glucose by Resurrection Bay (Alaska) sediments: functional group effects. Geochim. Cosmochim. Acta

Jones, B. N., Paabo, S., Stein, S. (1981). Amino acid analysis and enzymatic sequence determination by an improved $o-$ phthaldialdehyde precolumn labeling procedure. J. liquid Chromatogr. 4: 565-586

Jergensen, B. B. (1978). A comparison of methods for the quantification of bacterial sulfate reduction in coastal marine sediments. I. Measurement with radiotracer techniques. Geomicrobiol. J. 1: 11-27

King, G., Klug, M. J. (1982). Glucose metabolism in sediments of a eutrophic lake: tracer analysis of uptake and product formation. Appl. environ. Microbiol. 44: 1308-1317

Krom, M. D., Sholkovitz, E. R. (1977). Nature and reactions of dissolved organic matter in the interstitial waters of marine sediments. Geochim. Cosmochim. Acta 41: $1565-1573$

McDaniel, T. B. (1989). Biological availability of amino acids in marine sediments. M.S. thesis, University of Alaska, Fairbanks

Meyer-Reil, L.-A. (1986). Measurement of hydrolytic activity and incorporation of dissolved organic substrates by organisms in marine sediments. Mar. Ecol. Prog. Ser. 31: 143-149

Parkes, R., Taylor, J., Jork-Ramberg, D. (1984). Demonstration, using Desulfobacter spp., of two pools of acetate with different biological availabilities in marine porewater. Mar. Biol. 83: 271-276

Rice, D. L. (1982). The detritus nitrogen problem: new observations and perspectives from organic geochemistry. Mar. Ecol. Prog. Ser. 9: 153-162

Sansone, F. J., Martens, C. S. (1981). Determination of volatile fatty acid turnover rates in organic-rich marine sediments. Mar. Chem. 10: 233-247

Sansone, F. J., Andrews, C. C., Okamoto, M. Y. (1987). Adsorption of short-chain organic acids onto nearshore marine sediments. Geochim. Cosmochim. Acta 51: 1889-1896

Shaw, D. G., Alperin, M. J., Reeburgh, W. S., McIntosh, D. J. (1984). Biogeochemistry of acetate in anoxic marine sediments of Skan Bay, Alaska. Geochim. Cosmochim. Acta 48: $1819-1825$

Sumi, T., Koike, I. (1990). Estimation of ammonification and ammonium assimilation in surficial coastal and estuarine sediments. Limnol. Oceanogr. 35: 270-286

Manuscript first received: July 10, 1991

Revised version accepted: September 8, 1992 